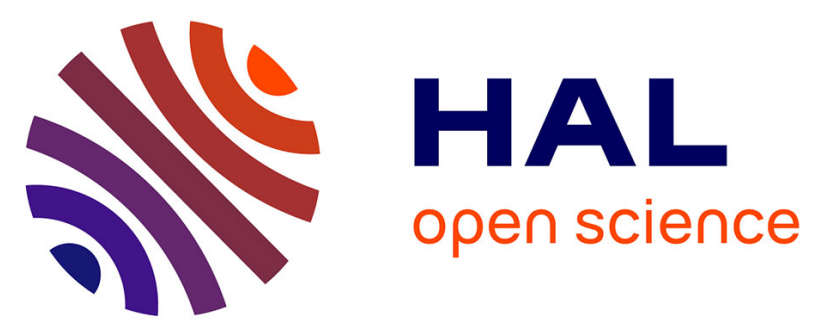

\title{
Bulky cation and four different polyiodide anions in [Lu(Db18c6)(H2O)3(Thf)6]4(I3)2(I5)6(I8)(I12)
}

Gerd Meyer, Glen Deacon, Peter Junk, Ingo Pantenburg, Christine Walbaum

\section{To cite this version:}

Gerd Meyer, Glen Deacon, Peter Junk, Ingo Pantenburg, Christine Walbaum. Bulky cation and four different polyiodide anions in $[\mathrm{Lu}(\mathrm{Db} 18 \mathrm{c} 6)(\mathrm{H} 2 \mathrm{O}) 3(\mathrm{Thf}) 6] 4(\mathrm{I} 3) 2(\mathrm{I} 5) 6(\mathrm{I} 8)(\mathrm{I} 12)$. Journal of Inorganic and General Chemistry / Zeitschrift für anorganische und allgemeine Chemie, 2010, 636 (8), pp.1444. 10.1002/zaac.201000112 . hal-00552470

\section{HAL Id: hal-00552470 \\ https://hal.science/hal-00552470}

Submitted on 6 Jan 2011

HAL is a multi-disciplinary open access archive for the deposit and dissemination of scientific research documents, whether they are published or not. The documents may come from teaching and research institutions in France or abroad, or from public or private research centers.
L'archive ouverte pluridisciplinaire HAL, est destinée au dépôt et à la diffusion de documents scientifiques de niveau recherche, publiés ou non, émanant des établissements d'enseignement et de recherche français ou étrangers, des laboratoires publics ou privés. 


\section{Bulky cation and four different polyiodide anions in [Lu(Db18C6)(H20)3(Thf)6]4(I3)2(I5)6(I8)(I12)}

\begin{tabular}{|r|l|}
\hline Journal: & Zeitschrift für Anorganische und Allgemeine Chemie \\
\hline Manuscript ID: & zaac.201000112.R1 \\
\hline Wiley - Manuscript type: & Communication \\
\hline Author: & 02-Apr-2010 \\
\hline Complete List of Authors: & $\begin{array}{l}\text { Meyer, Gerd; University of Cologne, Department of Chemistry } \\
\text { Deacon, Glen; Monash University, School of Chemistry } \\
\text { Junk, Peter; Monash University, School of Chemistry } \\
\text { Pantenburg, Ingo; University of Cologne, Department of Chemistry } \\
\text { Walbaum, Christine; University of Cologne, Department of } \\
\text { Chemistry }\end{array}$ \\
\hline Keywords: & $\begin{array}{l}\text { Bulky cation, Crown ether, Crystal structures, Lutetium, } \\
\text { Polyiodides }\end{array}$ \\
\hline
\end{tabular}

\section{ऽ ScholaroNE" \\ Manuscript Central}




\footnotetext{
* Corresponding Author Fax: (+49)221-470-5083 E-Mail: gerd.meyer@uni-koeln.de

[a] Department für Chemie, Institut für Anorganische Chemie Universität zu Köln, Greinstraße 6 D-50939 Köln, Germany

[b] School of Chemistry, Monash University Clayton, Victoria 3800, Australia
}

\section{Introduction}

The vast majority of polyiodides are triiodides. These can easily be made deliberately by the addition of elemental iodine to solutions which contain iodide anions and an appropriate cation. The triiodide anion, $\mathrm{I}_{3}^{-}$, is a linear 22 electron species (sometimes slightly bent due to packing effects) with three-centre-four-electron bonding obeying the Gillespie-Nyholm VSEPR concept; it is, therefore, a species in its own right. Higher polyiodide assemblies are loose connections between iodide, iodine and triiodide and may be put together, on paper, in a construction-kit manner. However, their distinction is not always beyond arbitrariness, often a matter of taste and follows selfmade rules, mostly based on distances.

Nevertheless, a large number of polyiodide anions have been observed in solids, ${ }^{[1,2]}$ and one has the impression that their design depends upon size and shape of the counter-cation(s). Therefore, we are in the process of testing cations of different charge, size and shape. Recent work has especially focussed on lanthanide ions in combination with various crown ethers. The number of respective reports in the literature is rather limited and all but one contain triiodide as the polyiodide anion. ${ }^{[3]}$ Surprisingly, the "exception", $\left[\operatorname{Pr}(\mathrm{B} 15 \mathrm{c} 5)_{2}\right] \mathrm{I}_{21},{ }^{[3 \mathrm{f}]}$ may be understood as having one of the rare higher anionic aggregates, $\mathrm{I}_{21}{ }^{3-}$; the world record is still held by $\mathrm{I}_{29}{ }^{3-} \cdot{ }^{[4]}$ We now report the isolation of $\left[\mathrm{Lu}(\mathrm{Db} 18 \mathrm{c} 6)\left(\mathrm{H}_{2} \mathrm{O}\right)_{3}(\mathrm{Thf})_{6}\right]_{4}\left(\mathrm{I}_{3}\right)_{2}\left(\mathrm{I}_{5}\right)_{6}\left(\mathrm{I}_{8}\right)\left(\mathrm{I}_{12}\right)$, a salt which contains both an exceptional cation and, in addition to $\mathrm{I}_{3}^{-}$, three higher polyiodide anions, $\mathrm{I}_{5}^{-}, \mathrm{I}_{8}{ }^{2-}$, and $\mathrm{I}_{12}{ }^{2-}$.

\section{Results and Discussion}

The reaction of elemental lutetium and iodine in Thf followed by the addition of dibenzo-18-crown-6 (Db18c6) resulted in a solution from which black single crystals of $[\text { cation }]^{3+}\left(\mathrm{I}_{14}\right)^{3-} \mathbf{1}$ grew after a prolonged period of time. ${ }^{[5]} \mathrm{A}$ crystal structure determination reveals that this simple formula needs to be rewritten as follows, $\left[\mathrm{Lu}(\mathrm{Db} 18 \mathrm{c} 6)\left(\mathrm{H}_{2} \mathrm{O}\right)_{3}(\mathrm{Thf})_{6}\right]_{4}\left(\mathrm{I}_{3}\right)_{2}\left(\mathrm{I}_{5}\right)_{6}\left(\mathrm{I}_{8}\right)\left(\mathrm{I}_{12}\right)$.

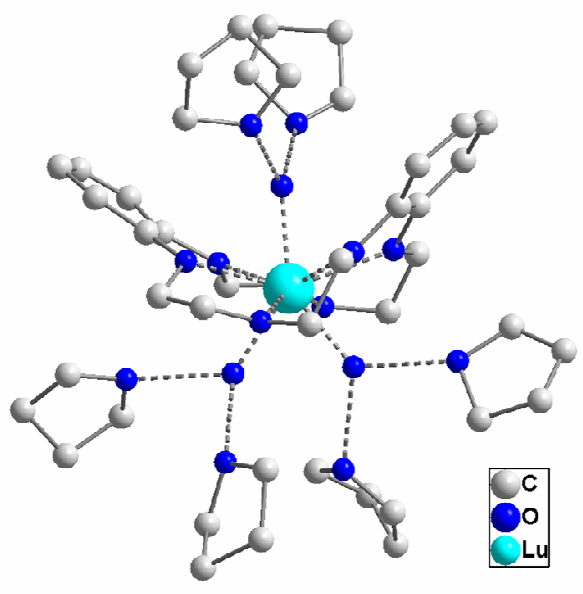

Figure 1. The cation $\left[\mathrm{Lu}(\mathrm{Db} 18 \mathrm{c} 6)\left(\mathrm{H}_{2} \mathrm{O}\right)_{3}(\mathrm{Thf})_{6}\right]^{3+}$ in the crystal structure of 1 .

The bulky cation $\left[\mathrm{Lu}(\mathrm{Db} 18 \mathrm{c} 6)\left(\mathrm{H}_{2} \mathrm{O}\right)_{3}(\mathrm{Thf})_{6}\right]^{3+}$ (Fig. 1) consists of a central $\mathrm{Lu}^{3+}$ cation surrounded by six oxygen atoms of Db18c6 and three water molecules in a tristar-like arrangement, a motif reminiscent of that seen in the simple molecular structure of $\left[\mathrm{Sm}(\mathrm{Db} 18 \mathrm{c} 6) \mathrm{I}_{3}\right] .{ }^{[6]}$ The Lu-O distances range from 226 to 255 pm (Db18c6) and 220-231 pm (water). Coordination numbers of (about) nine seem to be typical for crown ether-lanthanide(III) complexes, as is also attested by similar coordination environments in 
$\left[\mathrm{La}_{2}(\mathrm{Db} 18 \mathrm{c} 6)_{2}(\mathrm{OH})_{2} \mathrm{I}_{2}\right](\mathrm{I})\left(\mathrm{I}_{3}\right)^{[3 \mathrm{c}]}$ and $\left[\mathrm{Dy}_{2}(\mathrm{Db} 18 \mathrm{c} 6)_{2} \mathrm{Cl}_{4}\right]-$ $\left[\mathrm{Dy}_{2}\left(\mathrm{CH}_{3} \mathrm{CN}\right)_{2} \mathrm{Cl}_{8}\right]$, ${ }^{[7]}$ for example. So far, in our description, the cation would be rather usual; what makes it unusually big is the addition of six Thf molecules, two at each of the three water molecules of the complex cation, see Fig. 1.

The asymmetric unit contains 28 iodine atoms which are arranged, the centre of symmetry of space group $\mathrm{P} 2 / \mathrm{c}$ taken into account, in a fashion that Fig. 2 depicts.

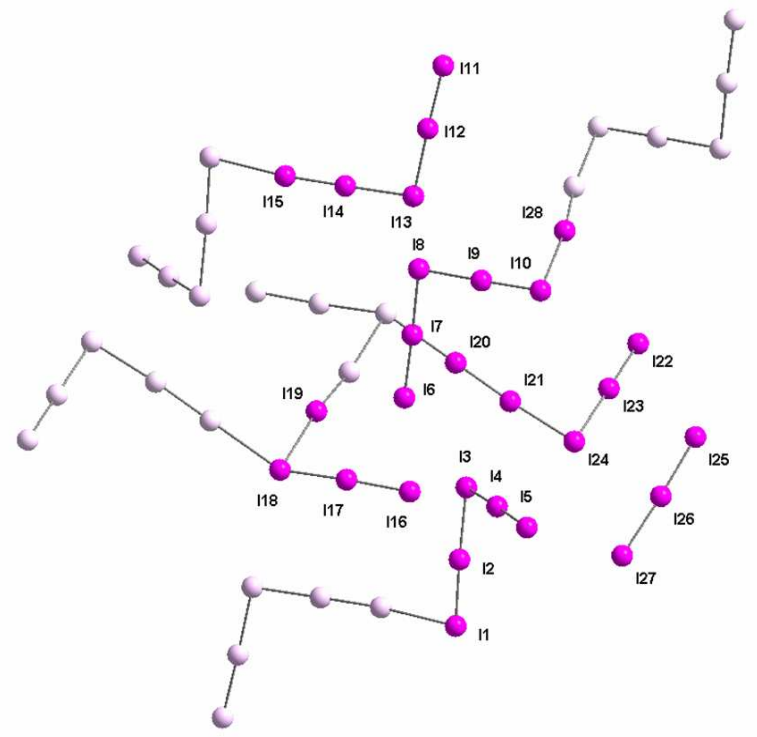

Figure 2. The four different polyiodide anions in the crystal structure of $\left[\mathrm{Lu}(\mathrm{Db} 18 \mathrm{c} 6)\left(\mathrm{H}_{2} \mathrm{O}\right)_{3}(\mathrm{Thf})_{6}\right]_{4}\left(\mathrm{I}_{3}\right)_{2}\left(\mathrm{I}_{5}\right)_{6}\left(\mathrm{I}_{8}\right)\left(\mathrm{I}_{12}\right)$ with their atomic numbering scheme. Atoms that do not belong to the asymmetric unit are drawn in a ligther pink.

The triiodide anion, $\left(\mathrm{I}_{3}\right)^{-}$, is slightly asymmetric and almost linear (I25-I26: 287.7(11), I26-I27: 296.2(11), I25I26-I27: 177.5(4); all distances here and in the following are given in units of picometres, pm, and angles in degrees). Through a long distance of 383.4(15) pm (I25-I11) it is weakly connected to one of the pentaiodide anions.

The crystal structure contains three crystallographically independent $\mathrm{V}$-shaped pentaiodide anions, $\left(\mathrm{I}_{5}\right)^{-}$, of the form $\left[\mathrm{I}_{2}-\mathrm{I}^{-}-\mathrm{I}_{2}\right]$ with typical bond distances and angles. ${ }^{[8]}$ These are for \#1: I1-I2: 280.8(13), I2-I3: 306.8(15), I3-I4: 315.7(14), I4-I5: 273.7(13), I1-I2-I3: 177.5(4), I2-I3-I4: 91.6(1), I3-I4-I5: 174.9(1); \#2: I11-I12: 284.5(11), I12-I13: 305.2(14), I13-I14: 310.9(14), I14-I15: 279.7(14), I11-I12I13: 177.9(4), I12-I13-I14: 102.0(3), I13-I14-I15: 177.2(4); \#3: I20-I21: $275.9(12), \quad$ I21-I24: $317.9(14), \quad$ I24-I23: 308.0(10), I23-I22: 280.4(11), I20-I21-I24: 174.6(1), I21I24-I23: $84.0(1)$, I24-I23-I22: 174.4(1). Two of the $\mathrm{I}_{5}$ anions may be seen as being connected via distances of 360.1(15) (I1-I15) to dimers. The third $\mathrm{I}_{5}^{-}$anion shows a distance in the same range (I20-I18: 362.2(15)) to the octaiodide anion.

The centrosymmetric octaiodide anions, $\left(\mathrm{I}_{8}\right)^{2-}=\left[\mathrm{I}_{2}-\mathrm{I}^{-}\right.$ $\left.-\mathrm{I}_{2}-\mathrm{I}^{-}-\mathrm{I}_{2}\right]$ are $\mathrm{Z}$-shaped and show bond distances and angles that are comparable to similar compounds. ${ }^{[9]}$ (I16I17: 284.8(10), I17-I18: 300.1(10), I18-I19: 343.0(13), I19I19': 273.5(16), I16-I17-I18: 176.9(4), I17-I18-I19: 85.4(4), I18-I19-I19': 171.6(1)).

The centrosymmetric dodecaiodide anion, $\left(\mathrm{I}_{12}\right)^{2-}$, is formally built up by two $\left(\mathrm{I}_{5}\right)^{-}$anions that are bridged by an iodine molecule (bold) resulting in a chain like structure, $\left[\mathrm{I}_{2}-\mathrm{I}^{-}-\mathrm{I}_{2}-\mathrm{I}_{2}-\mathrm{I}_{2}-\mathrm{I}^{-}-\mathrm{I}_{2}\right]$, with distances and angles of I6-
I7: 279.(11), I7-I8: 309.3(11), I8-I9: 299.3(11), I9-I10: 279.0(12), I10-I28: 347.1(13), I28-I28': 271.3(17); I6-I7-I8: 173.8(4), I7-I8-I9: 99.4(3), I8-I9-I10: 179.2(4), I9-I10-I28: 80.2(4), I10-I28-I28': 169.8(4). This motif is well known from the isotypic compounds $[\mathrm{M}(\mathrm{Db} 18 \mathrm{c} 6)]_{2} \mathrm{I}_{12}$ with $\mathrm{M}=\mathrm{K}$, $\mathrm{Rb}, \mathrm{Tl} .{ }^{[10]}$ The shortest intermolecular distance of 386.0(12) $\mathrm{pm}$ is observed between the $\left(\mathrm{I}_{12}\right)^{2-}$ anion and an $\left(\mathrm{I}_{8}\right)^{2-}$ anion (I6-I16).

The four polyiodide anions $\left(\mathrm{I}_{3}\right)^{-},\left(\mathrm{I}_{5}\right)^{-},\left(\mathrm{I}_{8}\right)^{2-}$, and $\left(\mathrm{I}_{12}\right)^{2-}$, in a ratio of $2: 6: 1: 1$, fill the three-dimensional space rather well, as Fig. 3 depicts, with no I-I distance between neighbouring anions longer than $400 \mathrm{pm}$, and leave space for four of the cations per formula unit as described above.

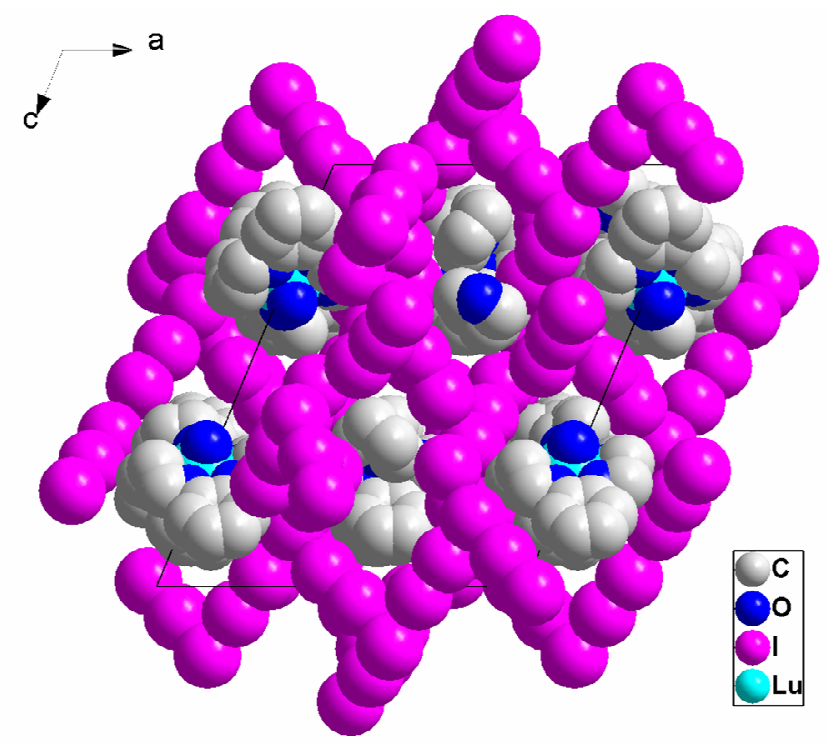

Figure 3. A space-filling model of the anionic polyiodide network, in which the bulky cations fit clearly well, in the unit cell of $\mathbf{1}$ projected along [010].

\section{Conclusions}

The reaction of lutetium metal and elemental iodine in Thf with the addition of Db18c6 resulted in black single crystals of $\left[\mathrm{Lu}(\mathrm{Db} 18 \mathrm{c} 6)\left(\mathrm{H}_{2} \mathrm{O}\right)_{3}(\mathrm{Thf})_{6}\right]_{4}\left(\mathrm{I}_{3}\right)_{2}\left(\mathrm{I}_{5}\right)_{6}\left(\mathrm{I}_{8}\right)\left(\mathrm{I}_{12}\right)$ with both an unusual cation coordination and four different polyiodide anions forming a three-dimensional network in which the large cations are encapsulated.

\section{Experimental Section}

Synthesis of 1: Iodine $(1.13 \mathrm{~g}, 4.5 \mathrm{mmol})$ and $20 \mathrm{~mL}$ Thf were added to a Schlenk flask under a nitrogen atmosphere which already contained lutetium powder $(0.18 \mathrm{~g}, 1 \mathrm{mmol})$. The reaction mixture was stirred over night at room temperature. A black solution was separated from a red precipitate via a filter canula. To the black solution dibenzo18-crown-6 (0.11 g, $0.3 \mathrm{mmol})$ was added causing the immediate precipitation of a brown solid. The reaction mixture was filtered and, after a few weeks, black polyhedral crystals grew from the filtrate. These are very sensititive and loose Thf and iodine when taken out of the mother liquor, a reason why we cannot report analytical data other than the crystal structure. 
Single crystals of $\mathbf{1}$ were selected from the mother liquor and were mounted on a glass fibre in silicone oil. The crystal quality was checked on a single-crystal X-ray diffractometer (Bruker X8 APEX II CCD) and a complete intensity data set was collected using graphitemonochromated Mo- $\mathrm{K}_{\alpha}$ radiation $(\lambda=71.073 \mathrm{pm})$. The data set was corrected for absorption (SADABS), then merged to 25697 unique reflections using the Bruker Apex II program suite. ${ }^{[11]}$ Further programs used are the WinGX suite of programs, ${ }^{[12]}$ including SIR-92 ${ }^{[13]}$ and SHELXL-97 ${ }^{[14]}$ for structure solution and refinement. The last refinement cycles included atomic positions for all the atoms, anisotropic thermal parameters for all the non-hydrogen atoms. The positions of the hydrogen atoms were calculated with the riding model and their isotropic thermal parameter fixed to be 1.2 times that of the parent atom.

Crystallographic data for the crystal structure of $\mathbf{1}$ have been deposited with the Cambridge Crystallographic Data Centre as supplementary publication no. 767937. Copies of the data can be obtained, free of charge, on application to CHGC, 12 Union Road, Cambridge CB2 1EZ, UK (fax: +44 1223336033 or e-mail: deposit@ccdc.cam.ac.uk).

Crystal data for 1: $\mathrm{C}_{176} \mathrm{H}_{312} \mathrm{I}_{56} \mathrm{Lu}_{4} \mathrm{O}_{60}, 11194.54 \mathrm{~g} \mathrm{~mol}^{-}$ ${ }^{1}$; diffractometer Bruker X8 APEX II CCD, T = 123(2) K; $2 \theta_{\max }=50.00^{\circ}$; one $\varphi$ - and two $\omega$-scans, 704 images; $-13 \leq \mathrm{h}$ $\leq 13,-17 \leq \mathrm{k} \leq 17,-16 \leq 1 \leq 16 ; \rho_{\text {calc }}=2.477 \mathrm{~g} \mathrm{~cm}^{-3} ; 16270$ measured reflections of which 3807 were symmetrically independent; $\mathrm{R}_{\mathrm{int}}=0.0478 ; \mathrm{F}(000)=10200 ; \mu=7.123 \mathrm{~mm}^{-}$ 1. Monoclinic, $P 2_{1} / c$ (no. 14), $a=2132.80(8), b=$ 2871.52(9), $c=2658.64(9) \mathrm{pm}, \quad \beta=112.792(2)^{\circ}, \quad V=$ 15011.1(9) $10^{6} \cdot \mathrm{pm}^{3}, Z=2$; $\mathrm{R}$ values: $\mathrm{R}_{1} / \mathrm{wR}_{2}$ for 3699 reflections with $\left[\mathrm{I}_{0}>2 \sigma\left(\mathrm{I}_{0}\right)\right]: 0.0999 / 0.2159$, for all data: $0.1012 / 0.2156 ; \mathrm{S}_{\text {all }}=1.227$.

\section{Acknowledgement}

This work was conducted as part of an ongoing informal collaboration between GBD and GM. Both the Universities of Cologne and Monash have supported a six-month stay of CW at Monash for which she is very grateful.

[1] K.-F. Tebbe, in Homoatomic Rings, Chains and Macromolecules of Main-Group Elements (Ed.: A. L. Rheingold), Elsevier, Amsterdam, Oxford, New York, 1997, pp. 551-606.

[2] P. H. Svensson, L. Kloo, Chem Rev. 2003, 103, 1649-1684.

[3] a) M. Safarpour Haghighi, M. Rath, H. W. Rotter, H. Homburg, Z. Anorg. Allg. Chem. 1993, 619, 1887-1896. b) S. Anfang, M. Karl, N. Faza, W. Massa, J. Magull, K. Dehnicke, Z. Anorg. Allg. Chem. 1997, 623, 1425-1432. c) C. Runschke, G. Meyer, Z. Anorg. Allg. Chem. 1997, 623, 14931495. d) R. J. Hill, D.-L. Long, M. S. Turvey, A. J. Blake, N. R. Champness, P. Hubberstey, C. Wilson, M. Schröder, Chem. Commun. 2004, 1792-1793. e) L. Huebner, A. Kornienko, T. J. Emge, J. G. Brennan, Inorg. Chem. 2004, 43, 5659-5664. f) I. Pantenburg, I. Müller, Z. Anorg. Allg. Chem. 2004, 630, 1637-1640. g) C. Walbaum, I. Pantenburg, G. Meyer, Z. Anorg. Allg. Chem. 2009, 635, 1083-1085.

[4] K.-F. Tebbe, R. Buchem, Angew. Chem. 1997, 109, 1403; Angew. Chem. Int. Ed. 1997, 36, 1345.

[5] C. Walbaum, Dissertation, Universität zu Köln, 2009.

[6] C. Runschke, G. Meyer, Z. Anorg. Allg. Chem. 1997, 623, 981-984.
[7] G. Crisci, G. Meyer, Z. Anorg. Allg. Chem. 1994, 620, 10231027.

[8] I. Pantenburg, K.-F. Tebbe, Z. Naturforsch. 2001, 56b, 271280.

[9] K. N. Robertson, P. K. Bakshi, T. S. Cameron, O. Knop, Z. Anorg. Allg. Chem. 1997, 623, 104-114.

[10] a) $\mathrm{M}=\mathrm{K}$ : K.-F. Tebbe, M. E. Essawi, Z. Anorg. Allg. Chem. 1998, 624, 1046-1050. b) $\mathrm{M}=\mathrm{Rb}$ : I. Pantenburg, Dissertation, Universität zu Köln, 2001. c) $\mathrm{M}=\mathrm{Tl}$ : C. Wieczorrek, Dissertation, Universität zu Köln, 2000.

[11] Apex II Version 2.1, Bruker AXS Ltd., Madison, Wisconsin.

[12] L. J. Farrugia, J. Appl. Crystallogr. 1999, 32, 837-838.

[13] A. Altomare, G. Cascarano, C. Giacovazzo, J. Appl. Crystallogr. 1993, 26, 343-350.

[14] G. M. Sheldrick, SHELXL-97; Programs for Crystal Structure Analysis, Universität Göttingen, 1997.

Received: ((will be filled in by the editorial staff)) Published online: ((will be filled in by the editorial staff)) 
Entry for the Table of Contents

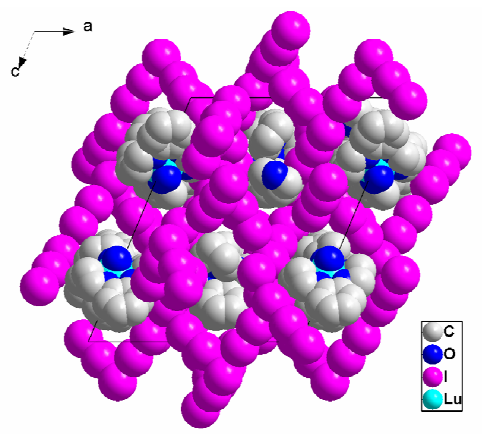

C. Walbaum, I. Pantenburg, P. Junk, G. B. Deacon, G. Meyer* Page No. - Page No.

Bulky cation and four different polyiodide anions in

$\left[\mathrm{Lu}(\mathrm{Db18c6})\left(\mathrm{H}_{2} \mathrm{O}\right)_{3}\left(\mathrm{Thf}_{6}\right]_{4}\right]_{4}\left(\mathrm{I}_{3}\right)_{2}\left(\mathrm{I}_{5}\right)_{6}\left(\mathrm{I}_{8}\right)\left(\mathrm{I}_{12}\right)$ 